\title{
A PROBABLE CASE OF KOUNIS SYNDROME AFTER BEE STINGS
}

\author{
Perihan Varim 1 , Ceyhun Varim², Mehmet Bulent Vatan', Sabiye Yilmaz ${ }^{1}$, Harun Kilic ${ }^{1}$ \\ ${ }^{1}$ Department of Cardiology, Sakarya University Medicine Faculty, Sakarya, Turkey \\ ${ }^{2}$ Department of Internal Medicine, Sakarya University Medicine Faculty, Sakarya, Turkey
}

\section{SLUČAJ VEROVATNOG KOUNISOVOG SINDROMA POSLE UJEDA PČELE}

\author{
Perihan Varim 1 , Cejhun Varim², Mehmet Bulent Vatan'1, Sabije Jilmaz'1, Harun Kilic ${ }^{1}$ \\ IInstitut za kardiologiju, Medicinski fakultet Sakarija Univerziteta, Sakarija, Turska \\ 2Institut za internu medicinu, Medicinski fakultet Sakarija Univerziteta, Sakarija, Turska
}

\begin{abstract}
Bee sting may cause hypersensitivity reaction with a range from simple allergic reaction to life-threatening anaphylactic response. Although rare, cardiac involvement is a possible complication, varying from vasospasm to acute ST-elevation myocardial infarction. In this case, a 61-year old man was presented to our hospital with ST elevation acute myocardial infarction of inferior wall after bee sting and he was immediately transferred to the cath lab for primary percutaneous coronary interventions. Coronary angiogram showed that the right coronary artery was occluded, angioplasty of the infarct related artery was successfully performed and the patient was transferred to the coronary care unit for further treatment. Patient status stabilized during the further clinical course and he was finally discharged with the appropriate maintenance drug therapy. The emergency physicians could be aware of the possibility of Kounis syndrome during hypersensitivity reactions in order to perform appropriate diagnostic and therapeutic measures in due time.
\end{abstract}

Key words: insect bites and stings; hypersensitivity, immediate; myocardial infarction.

\section{INTRODUCTION}

Kounis syndrome is characterized by symptoms ranges from vasospastic angina to ST elevation myocardial infarction (MI) (1). It is a hypersensitivity reaction which develops after allergen exposure. Initially, it was defined as allergic angina by Nicholas Kounis in 1991. Several drugs (NSAIDs, antibiotics, antineoplastic agents) and toxins such as the ones after a bee sting may cause Kounis syndrome (2). The basic pathophysiology of Kounis syndrome is degranulation of the mast cell, located in the tunica intima layer of coronary artery and atherosclerotic plaques, and the release of inflammatory mediators after the contact with an allergen (3). These mediators are biogenic amines such as histamine, neutral proteases such as chymase, tryptase, cathepsin-D, arachidonic acid derivatives such as leukotrienes and thromboxane (4). These inflammatory mediators cause vasoconstriction, plaque rupture and ischemic cardiovascular effects (5). Interstitial collagenase is fragmented to stromelysin and

\section{SAŽETAK}

Ujed pčele može izazvati reakciju preosetljivosti sa raznovrsnim ispoljavanjima od jednostavne alergijske reakcije do životno ugrožavajuće anafilakse. Iako retko, moguće su i srčane komplikacije, sa varijabilnom kliničkom slikom, od vazospazma do akutnog infarkta miokarda sa STelevacijom. U prikazanom slučaju, muškarac starosti 61 godine se javio u našu bolnicu zbog akutnog infarkta donjeg zida miokarda sa ST-elevacijom a posle ujeda pčele, zbog čega je odmah prebačen u kateterizacionu laboratoriju radi primarne perkutane koronarne intervencije. Koronarni angiogram je pokazao da je desna koronarna arterija okludirana zbog čega je uspešno sprovedena angioplastika arterije $u$ zoni infarkta $i$ bolesnik je potom preveden $u$ koronarnu jedinicu na dalje lečenje. Stanje bolesnika je tokom daljeg kliničkog toga stabilizovano tako da je on konačno otpušten sa odgovarajućom medikamentnom terapijom održavanja. Lekari koji zbrinjavaju urgentna stanja treba da imaju u vidu mogućnost pojave Kounisovog sindroma tokom reakcija preosetljivosti u cilju sprovodjenja odgovarajucih $i$ blagovremenih dijagnostičkih $i$ terapijskih mera.

Ključne reči: ujedi insekata $i$ ubodi; preosetljivost, neposredna; infarkt miokarda.

gelatinase by the action of tryptase. These molecules rupture atheromatous plaque and start acute inflammatory cascade which finally leads to thrombus formation (6). This mechanism was proposed by Kovanen in 1995 as a result of a study in which mast cell degranulation in patients with acute coronary syndrome was performed.

There are 3 types of Kounis syndrome (7). Type- 1 is represented with coronary artery spasm induced chest pain without predisposing factors and previous coronary artery disease (CAD). Type-2 occurs in patients with atheromatous coronary artery disease whereby the hypersensitivity reaction induces plaque rupture and acute myocardial infarction. Type-3 is characterized with eosinophils and mast cells which have been observed in the extracted thrombus material with hematoxylin-eosin and with Giemsa stain in patients with stent thrombosis after drug-eluting stent implantation. The levels of inflammatory markers such as prostaglandin D2, carboxypeptidase, CD63, interleukin 4 and 6, C-reactive 
protein and tryptase are to be measured in Kounis syndrome cases (8). Histamine is released about 5-10 minutes after mast cell degranulation and it must be measured in 30-60 minutes. Serum tryptase releases from the cardiac mast cells and causes plague rupture $(9,10)$.

\section{CASE REPORT}

A 61 years old male patient was presented to the emergency department $1 \mathrm{~h}$ after onset of retrosternal chest pain which had begun in 1-2 minutes after a bee sting. Cardiovascular risk factors such as hypertension, hyperlipidemia and smoking were absent while family history was unremarkable. The patient had diabetes mellitus type 2 and used oral antidiabetic drugs. There were the following findings on physical examination: common superficial abrasions connected to redness and itching were detected on the body, the patient's arterial pressure was 105/60 mmHg, pulse 107 beats per minute, respiratory rate 24 per minute. Respiratory and heart sounds were normal. The ST-segment elevation was found in D2, D3, AVF, V4-V6 leads of electrocardiogram (figure 1). After the initial examination, the patient was hospitalized at the coronary care unit with a diagnosis of acute ST-elevation myocardial infarction. After

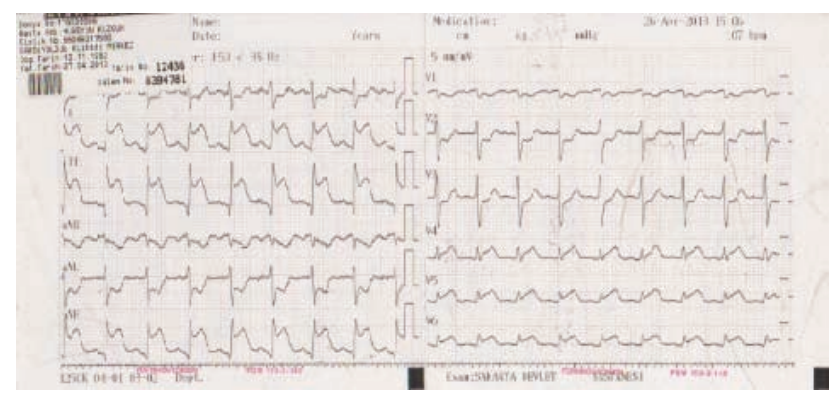

Figure 1. ST-segment elevation in D2, D3, AVF and V4V6 leads

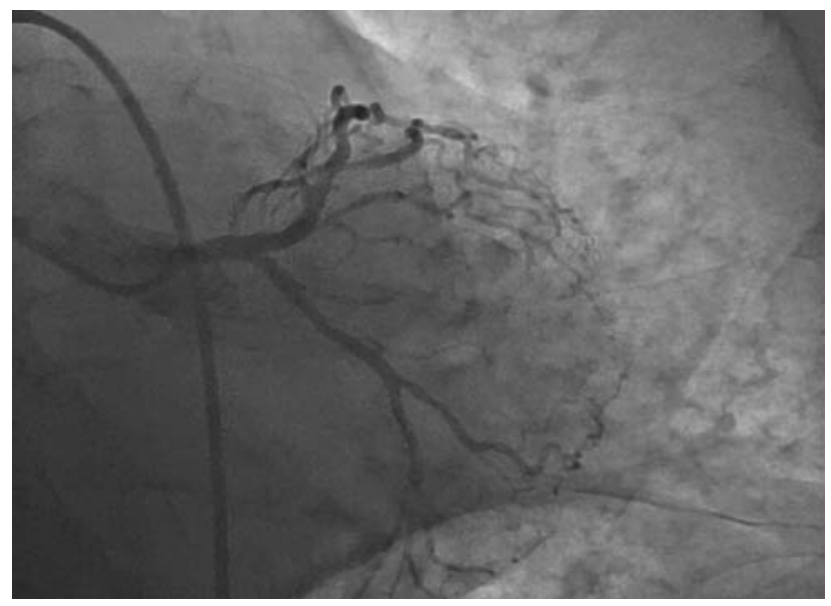

Figure 2. Stenosis of $40 \%$ in the left anterior descending D2, stenosis of $50 \%$ in the circumflex artery OM3, LMCA is normal pretreatment with $300 \mathrm{mg}$ of aspirin, $600 \mathrm{mg}$ of clopidogrel and 10.000 IU of heparin, intravenously. The patient was transferred to the cath lab. Selective coronary angiography was performed via the right femoral artery access route and demonstrated $40 \%$ diameter stenosis in the left anterior descending artery (LAD), 50\% diameter stenosis in the left circumflex artery (figure 2) and total occlusion in the right coronary artery (RCA) (figure 3). Percutaneous coronary intervention (PCI) of the infarct related artery was performed and the vessel was recanalized completely (Figure 4). The patient was free

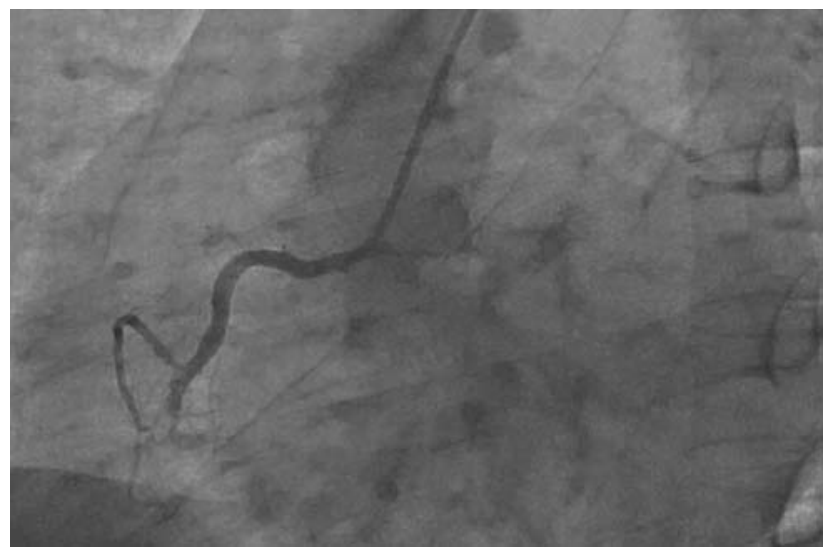

Figure 3. Total occlusion in the right coronary artery (RCA) after the right ventricular branch

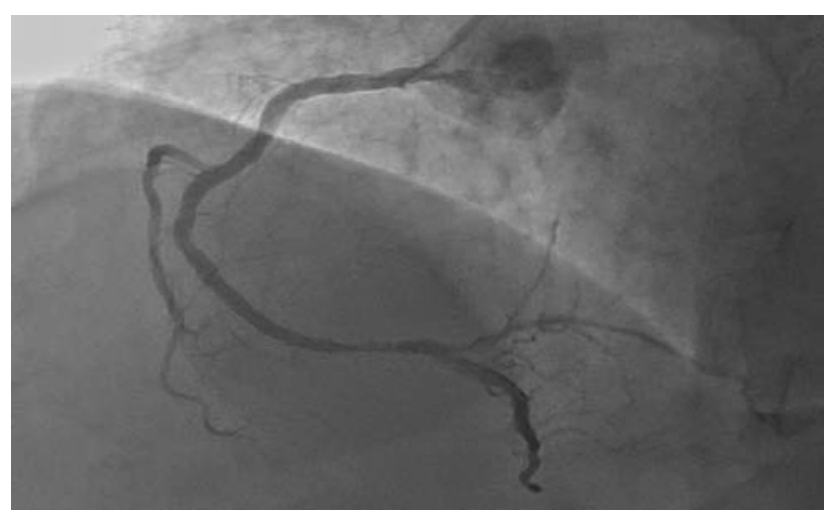

Figure 4. RCA after percutaneous coronary intervention

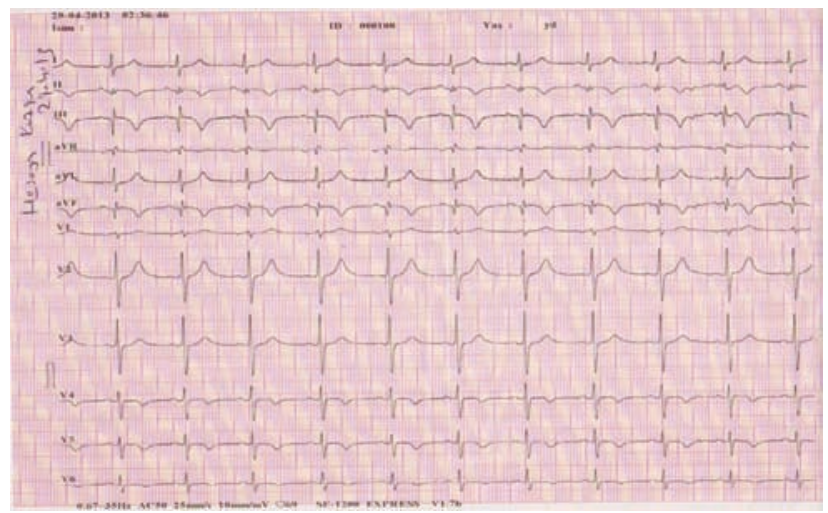

Figure 5. ECG after coronary angiography 
from symptoms and completely resolution of ST-segment was seen on ECG after the PCI (Figure 5). He was hospitalized at the coronary care unit for further followup. On echocardiography, the left ventricle ejection fraction was $50 \%$ with hypokinetic inferior wall, mild mitral regurgitation, mild aortic regurgitation and mild tricuspid regurgitation. The drug treatment was continued with aspirin, clopidogrel, ACE inhibitor and statin.

\section{DISCUSSION}

The treatment of Kounis syndrome consists of acute coronary syndrome (ACS) management and suppression of allergic reaction (7). The first line of treatment of coronary vasospasm includes nitrates and calcium channel blockers in the young, healthy patients with type 1 variant of Kounis syndrome, without the risk factors for CAD. Suppression of allergens in these patients with steroids and antihistamines may also resolve the coronary vasospasm. Acute coronary syndrome follow-up protocol and antihistaminic, steroid treatments should be considered in both type 2 and type 3 variant of the syndrome. The basic approach in the treatment of ACS is performing coronary angiography to to solve vasospasm with intracoronary agents or to perform primary PCI. Drugs, used in acute coronary syndrome, such as aspirin, clopidogrel, heparin, might cause themselves hypersensitivity reaction and they should be used carefully. Beta-blockers may exacerbate coronary vasospasm and suppress the action of rescue epinephrine and therefore, should be avoided.

In this case, we thought that the patient had the type 2 Kounis syndrome because he did not have cardiovascular risk factors, but he had a history of bee sting, and he had allergic symptoms such as rash, redness, hypotension and tachycardia. The treatment of acute coronary syndrome was made and the patient was taken to coronary intensive care. Antihistaminic treatment was not given because allergic symptoms had reduced during the disease course. After being discharged, the patient was referred to the allergy clinic for further diagnostics and treatment.

In conclusion, a detailed history should be taken from patients presenting with allergic symptoms to the emergency department. Cardiological examination should be done initially and, again after 8 hours. All doctors should consider Kounis syndrome in the differential diagnosis of allergic reactions as it could be a life-saving approach.

\section{REFERENCES}

1. Kounis NG, Zavras GM. Histamine-induced coronary artery spasm: the concept of allergic angina. Br J Clin Pract 1991; 45: 121-8.

2. Tok D, Ozcan F. Acute coronary syndromes developed after using parenteral penicillin: Kounis Syndrome, a case report. Arch Turk Soc Cardiol 2012; 40: 615-9.

3. Biteker M, Duran NE, Biteker F, et al. Kounis syndrome: first series in Turkish patients. Anatol J Cardiol 2009; 9: 59-60.

4. Genovese A, Spadaro G. Highlights in cardiovascular effects of histamine and H1-receptor antagonists. Allergy 1997; 52: 67-78.

5. Johnson JL, Jackson CL, Angelini GD, George SJ. Activation of matrix-degrading metalloproteinases by mast cell proteases in atherosclerotic plaques. Arterioscler Thromb Vasc Biol 1998; 18: 1707-15.

6. Gangadharan V, Bhatheja S, Al Balbissi K. Kounis syndrome - an atopic monster for the heart. Cardiovasc Diagn Ther 2013; 3: 47-51.

7. Kounis NG, Hahalis G, Manola A, Kourelis T, Theoharides TC. Kounis syndrome. Allergic angina and allergic myocardial infarction. In: Gallo AP, Jones ML. Angina pectoris: etiology, pathogenesis and treatment. Hauppauge: Nova Science Publishers, Inc. 2008: 77-150.

8. Sainte-Laudy J, Cado S. Comparison of the levels of histamine, tryptase, and interleukin- 6 for the investigation of anaphylactoid drug reactions. Allerg Immunol (Paris) 1998; 30: 209-11.

9. Bjornsson HM, Graffeo CS. Improving diagnostic accuracy of anaphylaxis in the acute care setting. West J Emerg Med 2010; 11: 456-61.

10. Kounis NG. Serum tryptase levels and Kounis syndrome. Int J Cardiol 2007; 114: 407-8. 